\title{
Article \\ Cloning and Characterization of an Alginate Lyase from Marine Vibrio. sp. QD-5
}

\author{
Yaxi Chao ${ }^{1}$, Shuyan Wang ${ }^{1}$, Suqi Wu ${ }^{1,2}$, Jiaqiang Wei ${ }^{1}$, Hao Chen ${ }^{1,2^{*}}$ \\ 1 Key Lab of Marine Bioactive Substances, First Institute of Oceanography, State Oceanic Administration, \\ Qingdao 266061, China; E-Mails: yaxichao@163.com (Y.C.); 649788135@qq.com (S.W.); \\ wusuqi@fio.org.cn (S.W.); wjqmrchilren@163.com (J.W.) \\ 2 Laboratory for Marine Biology and Biotechnology, Qingdao National Laboratory for Marine Science and \\ Technology, Qingdao 266237, China \\ * Author to whom correspondence should be addressed; E-Mail: hchen@fio.org.cn; \\ Tel. /Fax: +86-532-8896-3855.
}

\begin{abstract}
The string of bacteria, Vibrio. sp. QD-5 utilizing alginate, was separated from rotten kelp. The results of genome sequencing showed that the strain QD-5 contained four alginate lyase genes.One of the alginate genes Aly-IV was cloned and linked to the plasmid pET-22b (+). The heterologous expressed alginate lyase aly-IVwas characterized, which possessed the theoretical molecular mass of $62 \mathrm{kDa}$, and theoretical isoelectric point (pI) of 5.12. - The enzyme aly-IV was purified and the activity reached $1256.78 \mathrm{U} / \mathrm{mg}$, with optimal temperature of $35^{\circ} \mathrm{C}$ and $\mathrm{pH}$ value of 8.9. Nurtured in the temperature below $25^{\circ} \mathrm{C}$ for 30 minutes, the activity was almost stable. The result also suggested that the activity of enzyme was strongly affected by $-\mathrm{NaCl}$ whose optimal concentration was $15 \mathrm{mM}$ in a lab environment The TLC and ESI-TOF-MS analysis suggested that the enzyme aly-IV could degrade sodium alginate and polyG in endo-lytic type, producing monomer, dimer and trimmer. So, aly-IV can also be widely applied to make large scale preparation of alginate oligosaccharides with low degree of polymerization (DP).
\end{abstract}

Keywards: alginate lyase; Vibrio sp.QD-5; alginate

\section{Introduction}

Alginates are unbranched polymer- comprised of $-\alpha$-L-guluronic acid $(G)$ and its C5 epimer $\beta$-D-mannuronic acid (M). The monomers can form the homopolymeric polyG, polyM, and heteropolymeric polyMG in alginates by the different arrangement[1]. Because of the distinctive chemical and physical properties, alginates were widely used in many fields [2], such as ingredients, stabilizers and thickeners in the food and beverage industry [3]. In addition, alginates could also function as a thickening agent in fabric printing, adhesive agent and filler in paper industries, stabilizer cum suspending agent in paints, a novel way of ceramic shaping in gelcasting, and biocatalysts in water treatments [4]. In the healthcare and pharmaceutical industry, alginates were also a growing importance.. Alginates were involved in tablet making to improve bioadhesive property for buccal adhesive tablets [5]. Alginate $(10-100 \mathrm{kDa})$ could potentially combat hypercholesterolemia and diabetes mellitus [6]. Due to the strong gelation and less easily absorbed in vivo, , the application of alginates waslargely limited in medicine [7]. The research revealed that the oligosaccharides from alginatesare easily dissolved, highly stable and nontoxic. They could be used to resist virus, restrain the growth of some bacteria and promote the growth of plants [8,9].

Alginate lyases have been separated from various sources, including marine algae, marine mollusks, marine bacteria, soil bacteria, fungi and viruses [10]. These lyases were used to break the glycoside bond in alginate through $\beta$-elimination mechanism to form a double band between $\mathrm{C} 4$ and $\mathrm{C} 5$ at the non-reducing end of the degrading product. [10]. According to their different substrate specificities, alginate lyases were categorized into M-specific lyase (EC 4.2.2.3), G-specific lyase (EC 4.2.2.11). . In terms of mode action, the alginate lyases were also classified into endolytic 
and exolytic enzyme [10]. So far, various alginate lyases have been cloned and characterized [11].Based on their primary structures, the alginate lyases were also grouped into seven polysaccharide lyase families in the Carbohydrate Active Enzyme (CAZy) database (http://www.cazy.org/), such as PL-5, PL-6, PL-7, PL-14, PL-15, PL-17, and PL-18 [12]. The problem concerning the crystal structures of various alginate lyases were solved, A $\beta$-sandwich-likefold structure with a large active cleft covered by 2 short flexible loops was shared in PL7 alginate lyases10]. Now, alginate lyases have been widely used for different purposes, such as analysis of the alginate structure [13], extraction of the algal protoplasts [14], and biofilm degradation of mucoid Pseudomonas aeruginosa [15].

In this study, an alginate lyase-producing bacteria Vibrio sp. QD-5 was isolated from rotten kelp. An alginate lyase gene (Aly-IV) was cloned from this strain and expressed in Escherichia coli BL21 (DE3). Biochemical properties of the alginate lyase (aly-IV) were characterized after purification. The reaction mode and final degradation products of the recombinant enzyme were also analyzed.

\section{Results and Discussion}

\subsection{Isolation of alginate-degrading bacteria and phylogenetic analysis}

The rotten kelp samples were spread on the alginate plates. After being incubated at $28{ }^{\circ} \mathrm{C}$ for $72 \mathrm{~h}$, several hollows emerged (Figure 1A). The colons digging holes on the plates were picked up and purified three times on the same medium, for their potential ability of alginate-degrading. In this article, QD-5 was selected for the following researches. The $16 \mathrm{~S}$ rRNA gene of strain QD-5 was sequenced and submitted to Genebank (accession number PRJNA382465). A $1437 \mathrm{bp}$ fragment of the gene was aligned with other strains The closest stain was Vibrio alginolyticus string W047 (JF836178.1). Combined with the phylogenetic position (Figure 1B), QD-5 was named Vibrio sp. QD-5 (Figure 1).

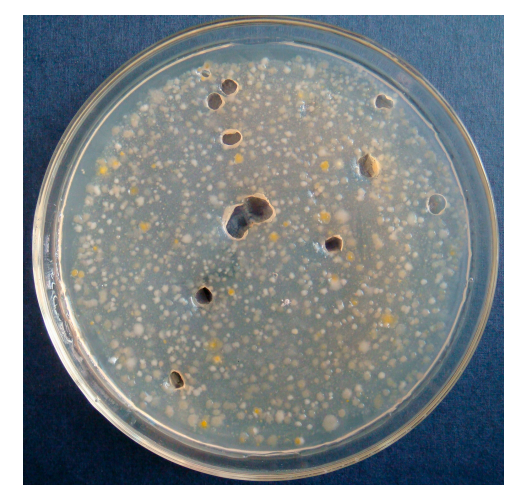

Figure 1A. Hollow zones on the plate. The colons digging holes on the plates had the potential of digest alginate. 


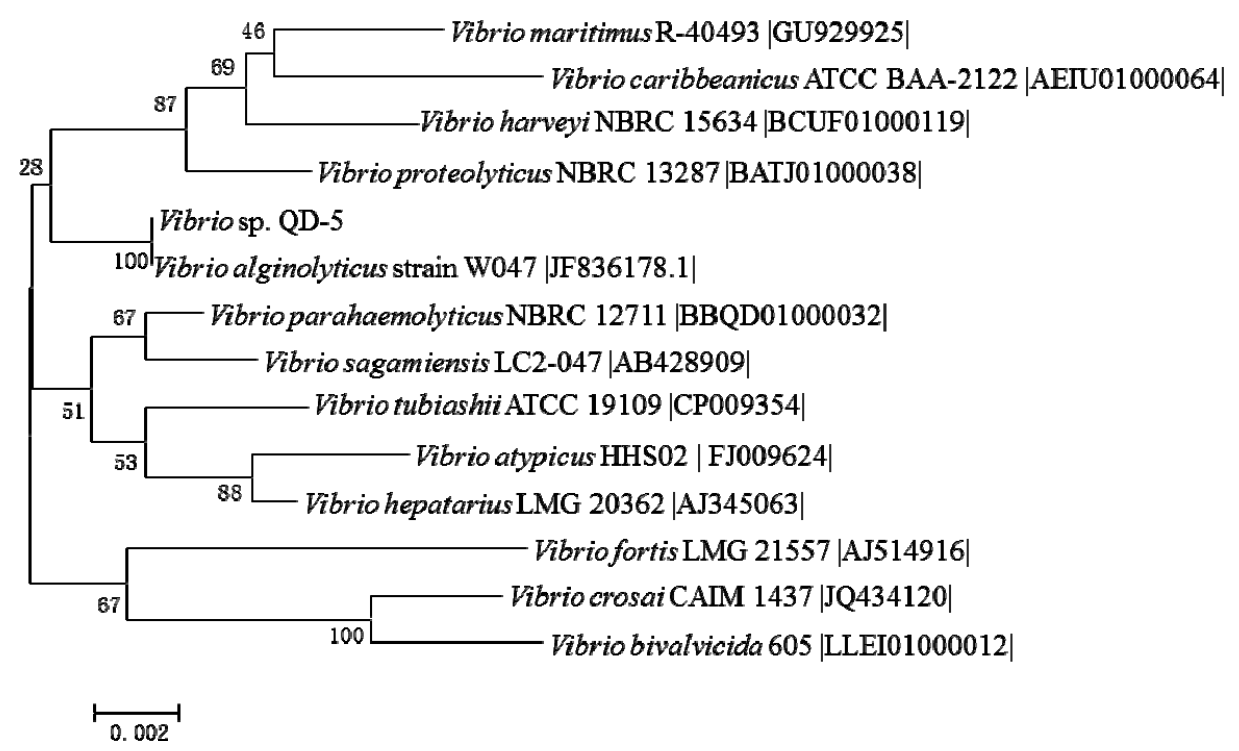

Figure 1B. Phylogenetic analysis of strain QD-5. Phylogenetic tree was constructed through the neighbor-joining algorithm using MEGA6.0, and the evolutionary distance was estimated by the maximum composite likelihood (MCL) method [16].

\subsection{Information about the Aly-IV gene and the deduced amino acid sequence}

Using the sequenced genomic datas extracted from an Illumina Hiseq sequencing run, the draft genome of the Vibrio sp. QD-5 was constructed. It consists of two circular chromosomes whose sizes are at about $3.3 \mathrm{M} \mathrm{bp}$ and about $1.8 \mathrm{M}$ bp (Figure 2A). The genome sequence has been submitted to Genebank (accession number PRJNA382465). The cluster of alginate lysae genes located on the chromosome 2 was found (Figure 2B). One of the genes,Aly-IV, was amplified by PCR.It encoded a predicted protein with 560 amino acids including a putative signal peptide sequence of 22 amino acid residues ( $\mathrm{Met}^{1}$ to $\mathrm{Ala}^{22}$ ) (Figure 3). The molecular mass of the aly-IV was approximately $62 \mathrm{kDa}$. The theoretical isoelectric point $(\mathrm{pI})$ was 5.12. Conserved domain analysis of the putative protein revealed that the protein was classified into F5/8 type $\mathrm{C}$ and Alginate lyase2 domain. F5/8 type C domain in aly-IV was from $\mathrm{Thr}^{77}$ to $\mathrm{Leu}^{195}$ which was also known as the discoidin (DS) domain family (Figure 3). Alginate lyase2 domain in aly-IV was from Phe ${ }^{284}$ to Lys $\mathrm{s}^{545}$ (Figure 3). It was a member of pfam08787 which have a predominantly beta sheet structure [17]. Analysis of the protein primary structure revealed that the Alginate lyase2 was assigned to polysaccharide lyase family 7 (PL7). Sequence alignment of Alginate lyase2 in aly-IV with other PL7 alginate lyases indicated that the conserved motifs in aly-IV were RTELR, YFKNGVYNQ and QIH, which were highly conserved motifs in PL7 alginate lyases (Figure 4). The three conserved motifs composed the active center of the alginate lyase and were crucial for substrate recognition and catalysis [18-20]. 

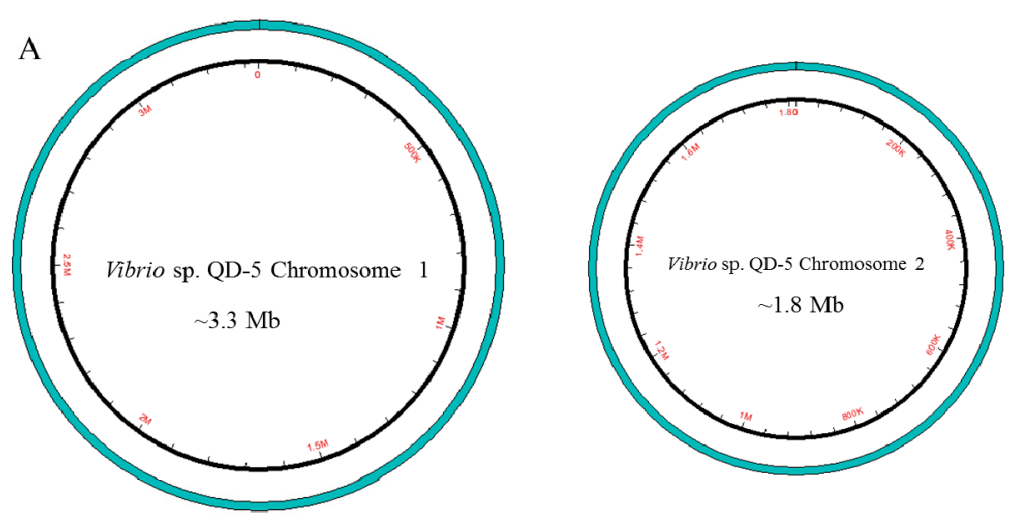

B

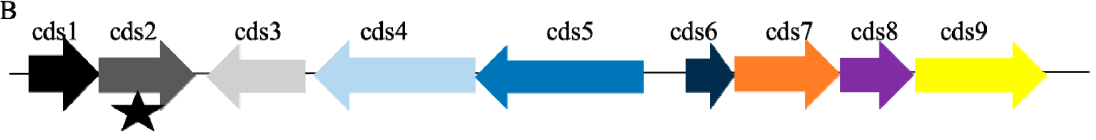
putative oligogalacturonate specific
porin precursor, gene
algiante lyase precursor (alyVMIV) gene

alginate lyase (alyVMIII) gene

algiante lyase (alyVMII) gene

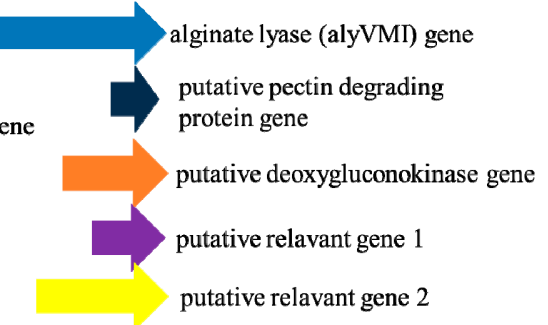

Figure 2. The genome and alginate lyase gene cluster of the Vibrio sp. QD-5. (A) The draft genome of the strain Vibrio sp. QD-5 (B) Four alginate lyase genes in the genome of the Vibrio sp.QD-5, they were cds2, cds3, cds4, cds5. The cds1, cds6, cds7, cds8, cds9 were the genes relevant to the alginate lysae gene. The asterisk is the position of Aly-IV.

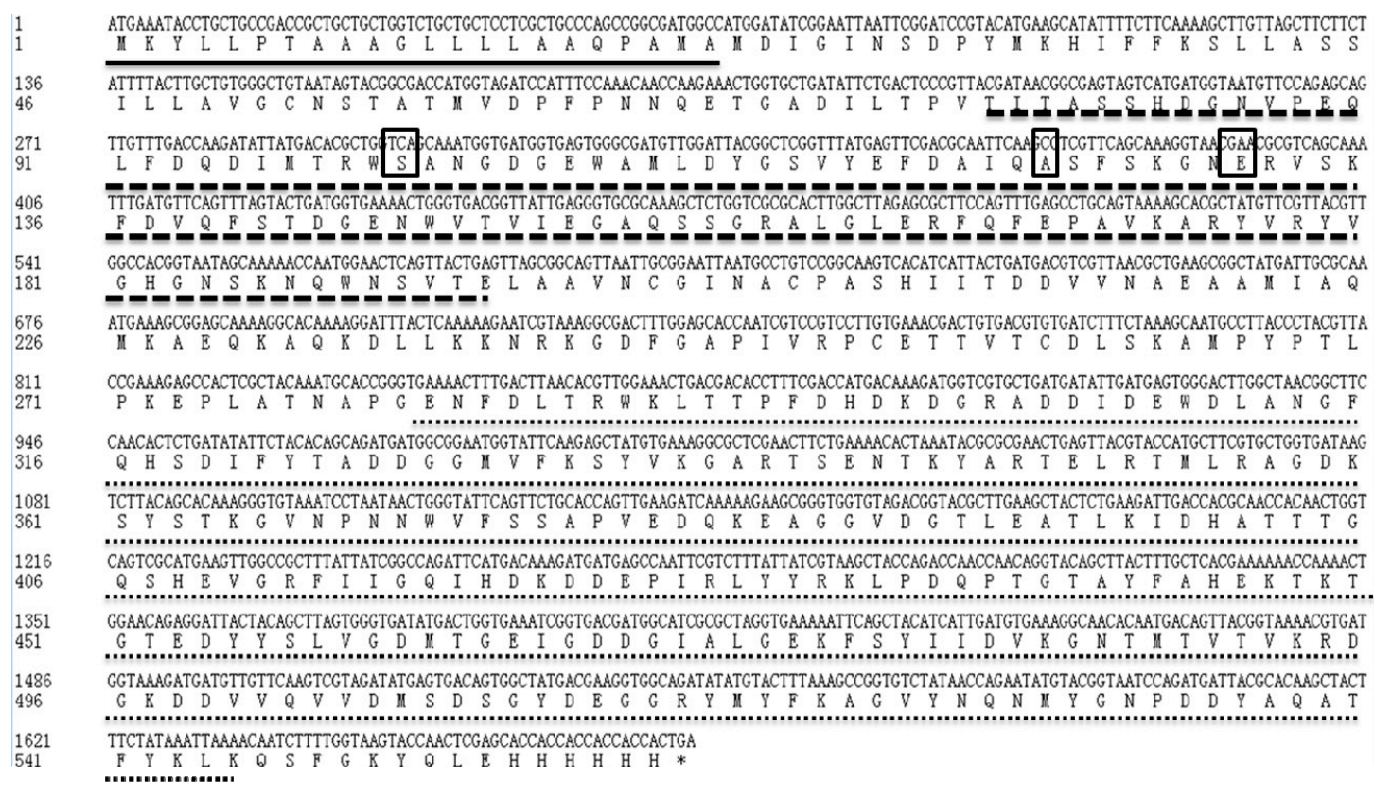

Figure 3. Nucleotide and deduced amino acid sequence of the Aly-IV. The signal peptide was underlined straight line. Dashed line was the F5/8 type $\mathrm{C}$ domain. The dotted line was Alginate lyase2 domain. The location of the boxes were the sugar binding sites 


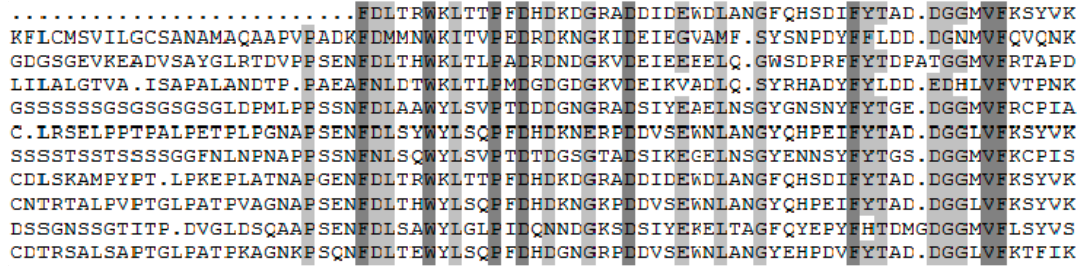

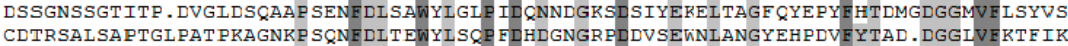

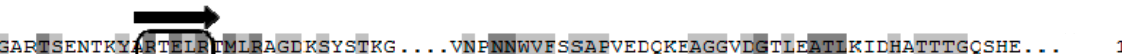

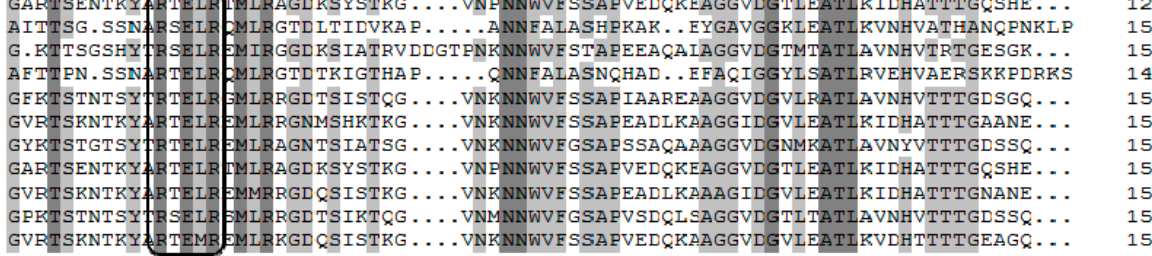
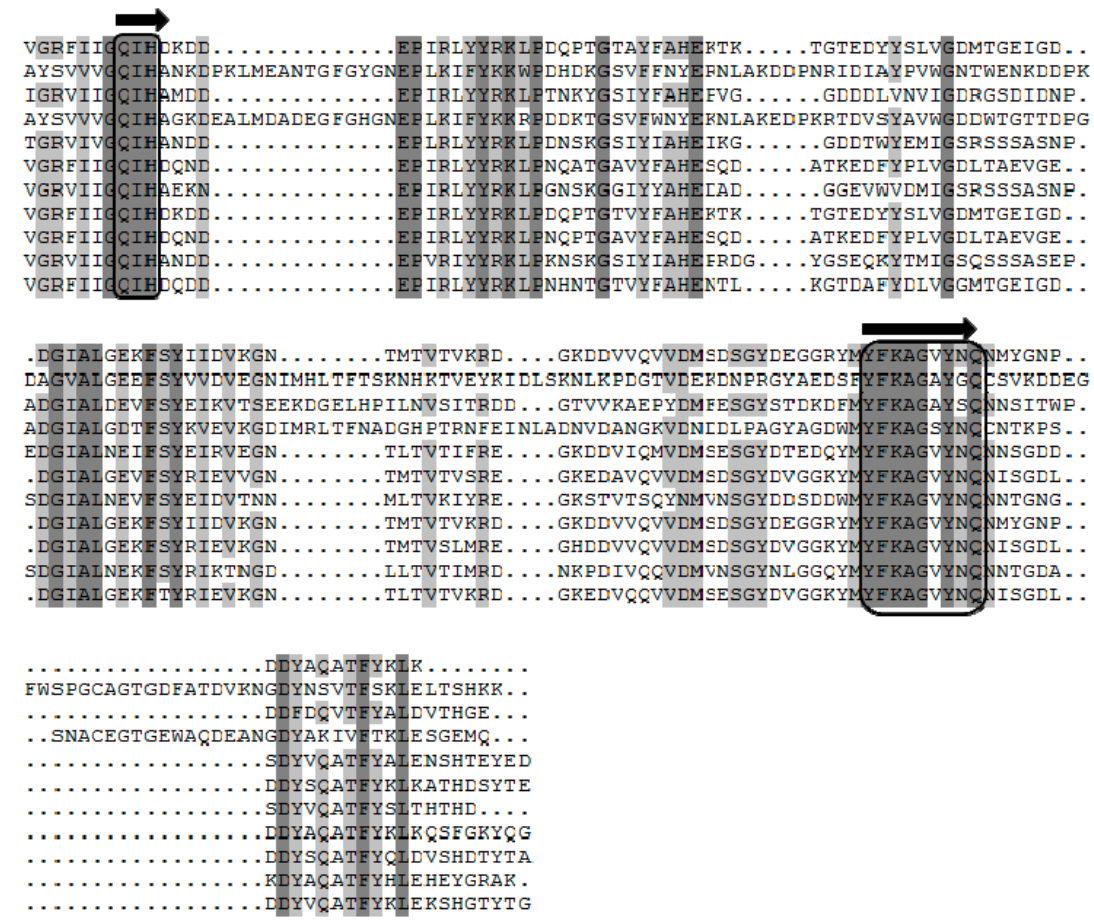

a $1 \mathrm{Y}$-IV

BAV53312.

BAV10560.

BA 62034.1

मCM 9454

BAK40155.

ADW

ALP75563. 1

ALP75562.

alY-IV

BAV53312.

BAV10560.

ANB32492.1

ACM 9454 .

BAK40155.

ADW 41663 .

BAH79133.

ALP75563.

ALP75562.1

aly-IV

BAV53312.

BAV10560.

ANB32492.

BAJ 62034 .

AcM 9454.

BAK 0155.1

A.DW41663.

ALP75562 .

Figure 4. Amino acid alignment of aly-IV with other PL7 alginate lyase. BAV53312.1, an alginate lyase from Vibrio algivorus; BAV10560.1, an endo-type alginate lyase from Falsirhodobacter sp. alg1; ANB32492.1, an alginate lyase from Halomonas sp. Victoria JH; BAJ62034.1, an alginate lyase from Microbulbifer sp. 6532A; ACM89454.1, an alginate lyase from Pseudoalteromonas sp. CY24; BAK40155.1, an alginate lyase from Saccharophagus sp. Myt-1; ADW41663.1, an alginate lyase precursor from Vibrio midae; BAH79133.1, an alginate lyase from Vibrio sp. A9m; ALP75563.1, an alginate lyase from Vibrio sp. BZM-1; ALP75562.1, an alginate lyase from Vibrio litoralis. Similar amino acid residues among the alginate lyases were shaded in gray. Conserved regions were boxed.

\subsection{Purification of the recombination enzyme aly-IV.}

To characterize the recombinant enzyme, the gene Aly-IV was cloned into an expression vector pET-22b (+) and expressed in BL21. Tests showed the recombinant enzyme, aly-IV, was expressed in the form of inclusion bodies (IB). For obtain the active enzyme aly-IV, the IB was denatured by Sarkosyl and refolded via dilution. A large amount of renaturation enzyme were obtained and purified by nickel affinity chromatography followed by gel filtration chromatography. The apparent molecular weight was about $62 \mathrm{kDa}$ on the SDS-PAGE (Figure 5). The final activity of the enzyme reached $1256.78 \mathrm{U} / \mathrm{mg}$, which was different from the alginate lyase from other Vibrio sp.. 


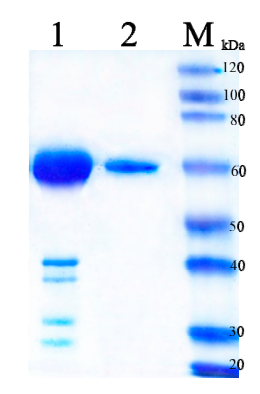

Figure 5. SDS-PAGE analysis of the purified enzyme aly-IV. Proteins were electrophoresed on $12.5 \%$ acrylamide gel and stained with Coomassie Brilliant Blue G-250. Lane 1: $10 \mu \mathrm{L}$ of the protein (150 $\mu \mathrm{g} / \mathrm{mL}$ ) purified by Ni-NTA affinity chromatography. Lane M: protein mass markers. Lane 2: $20 \mu \mathrm{L}$ of the protein $(10 \mu \mathrm{g} / \mathrm{mL})$ purified by Superdex-200 Increase10/300.

\subsection{Characteristics of the recombinant enzyme aly-IV}

The optimal temperature of the enzyme aly-IV was $35^{\circ} \mathrm{C}$ (Figure $6 \mathrm{~A}$ ) and remained stable when incubated in the temperature below $30^{\circ} \mathrm{C}$ for $30 \mathrm{~min}$ (Figure 6B). The optimal pH of the enzyme activity was 8.9 (Figure 6C). The enzyme activity was more than $80 \%$ when the reaction $\mathrm{pH}$ ranges from $\mathrm{pH} 7.0$ to $\mathrm{pH}$ 10.0. The residual activity of the enzyme showed more than $70 \%$ after being incubated in the Glycine-NaOH buffer (pH9.6-10.5) for $3 \mathrm{~h}$ on the ice (Figure 6D).

The $\mathrm{pH}$ stability of the enzyme was related to the type of the buffer. In the $\mathrm{Na}_{2} \mathrm{HPO}_{4}$-Citric acid buffer ( $\mathrm{pH} 5.5-6.0$ ), the residual activity was maintained less than $25 \%$. In the PB buffer (pH 5.8-8.0), the residual activity was lower than $70 \%$ of the initial activity. In the Tris-HCl buffer (pH 7.0-8.9), the activity was more than $50 \%$. Notably, in the Tris- $\mathrm{HCl}$ buffer $\mathrm{pH} 7.0$, the enzyme activity was almost unaffected. When the glycine- $\mathrm{NaOH}$ buffer was used the trend of the effects on the activity was a parabolic curve. The highest residual activity was in the buffer of $\mathrm{pH} 9.6$; the lowest residual activity was in the buffer of $\mathrm{pH} 9$ with $42 \%$ against the initial activity. The enzyme aly-IV showed different activity in the different buffers at the same $\mathrm{pH}$, suggesting that the buffer ions affect the enzyme activity.
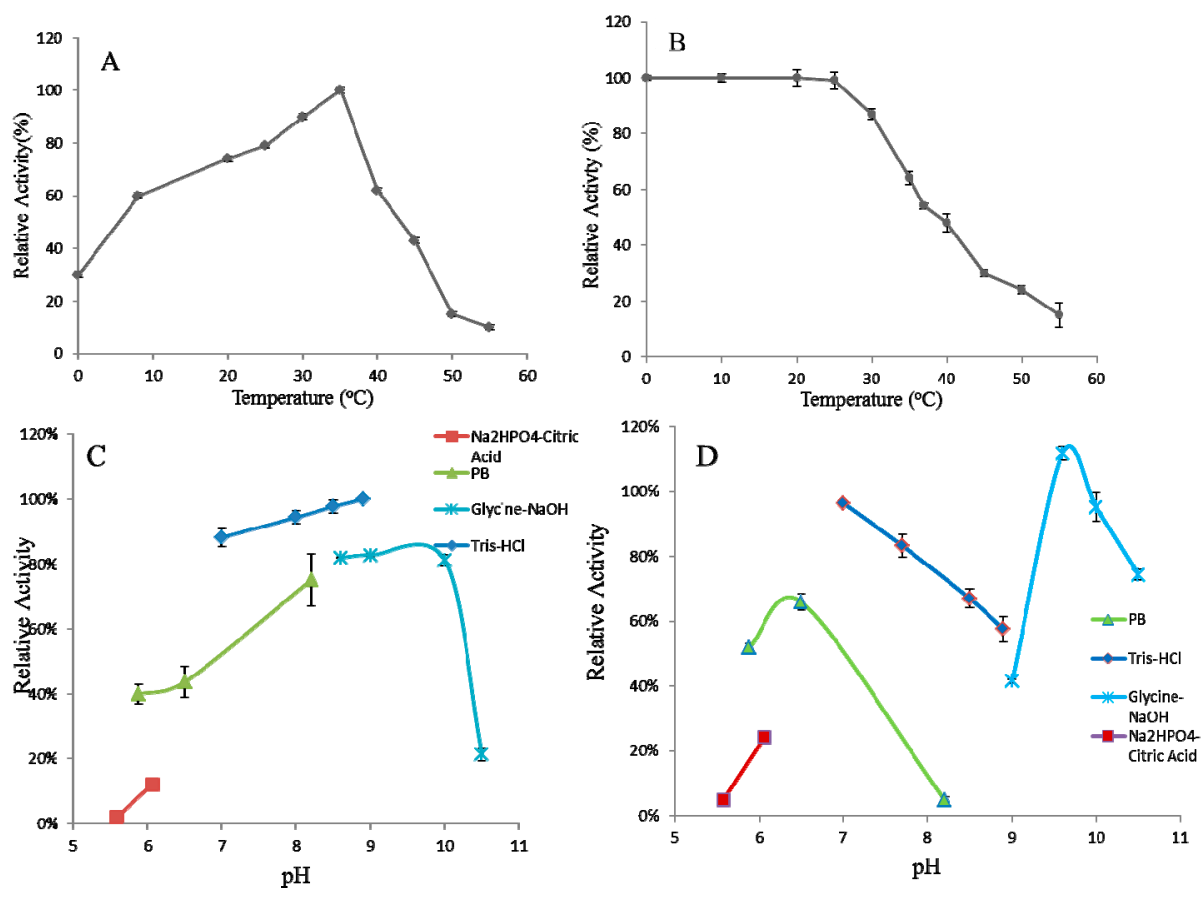

Figure 6. Biochemical characterization of the recombinant alginate lyase aly-IV. (A) The optimal temperature of aly-IV. (B) Thermal stability of aly-IV. (C) The optimal pH of aly-IV. (D) pH stability of aly-IV was determined by measuring the residual activity after the enzyme incubated in the $\mathrm{pH}$ range of 5-10.5 with the above buffer for $3 \mathrm{~h}$ in ice-bath. 
The effects of the $\mathrm{NaCl}$ on the activity of the enzyme aly-IV showed in Figure 7A. The enzyme activity was $\mathrm{T}$ inhibited when the concentration was more than $20 \mathrm{mM}$.. Moreover,The activity of aly-IV was strongly inhibited by $1 \mathrm{mM}, \mathrm{Ba}^{2+}, \mathrm{Al}^{3+}, \mathrm{Ni}^{2+}, \mathrm{Zn}^{2+}, \mathrm{Pb}^{2+}$ and $\mathrm{EDTA}^{2-}$, but promoted by $1 \mathrm{mM}$ $\mathrm{Ca}^{2+}$ (Figure 7B), increased with $\mathrm{K}+$ and $\mathrm{Mg}^{2+}$ at the concentration of $5 \mathrm{mM}$ and $10 \mathrm{mM}$.
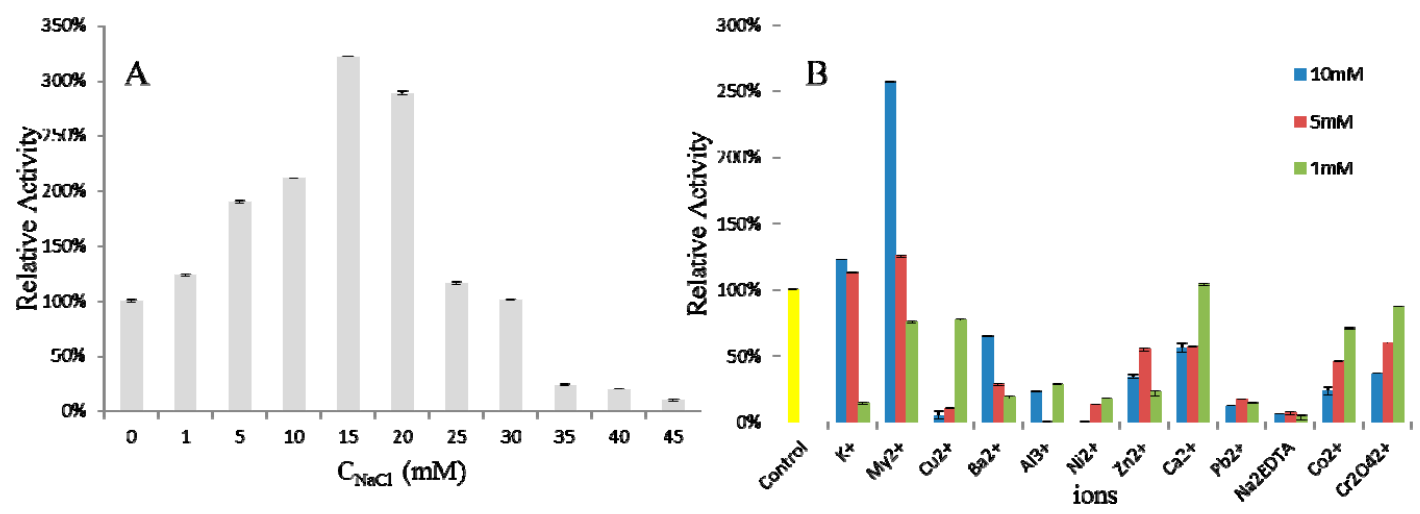

Figure 7. The effects of $\mathrm{NaCl}(\mathrm{A})$ and metal ions (B) on the enzymatic activity of aly-IV.

\subsection{Enzymtic Hydrolysis of sodium alginate by aly-IV}

To study degradation characteristics of aly-IV, the amount of degradation product was determined by the time length. As shown in Figure S8, when the reaction time increased from $0.5 \mathrm{~h}$ to $6 \mathrm{~h}$, the amount of product was increasing considerably. After 6 hours, the increase of the product was not significant due to the loss of the enzyme activity after incubation at $35^{\circ} \mathrm{C}$ for a long time.

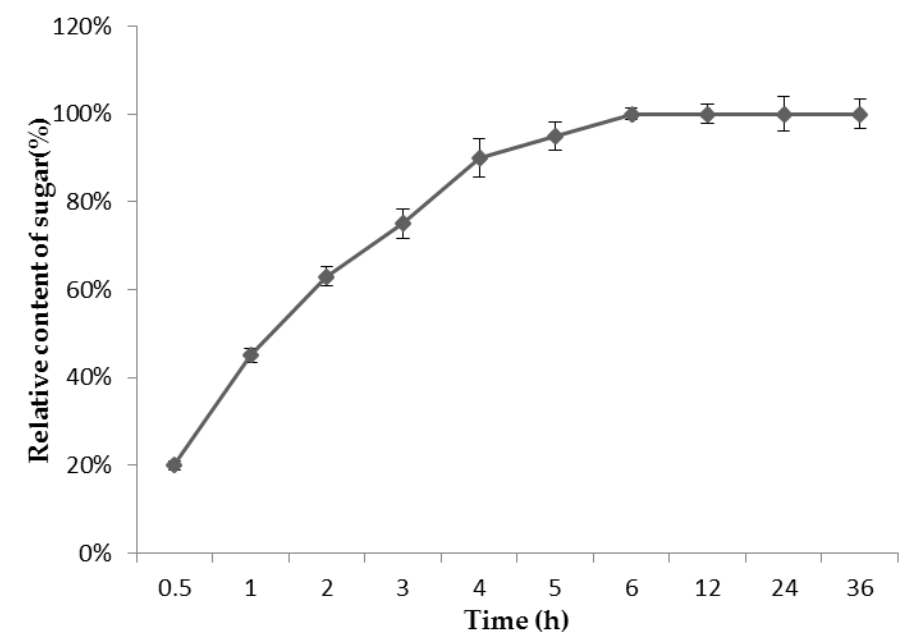

Figure S8. Enzymtic Hydrolysis of sodium alginate by aly-IV. The highest OD520 was set to be $100 \%$.

\subsection{Substrate Specificity and Km Values of the Recombined Enzyme}

To research intothe substrate specificity, sodium alginate, polyG, polyM and polyGM were used as the substrates of the recombinant enzyme aly-IV. The datas revealed that aly-IV preferred sodium alginate and polyG, no activity toward polyM and polyGM(Table 1)

The $K \mathrm{~m}$ values of the enzyme towards sodium alginate and polyG were $0.2223 \mathrm{~g} / \mathrm{ml}$, and 0.3274 $\mathrm{g} / \mathrm{ml}$, respectively (Table 1 ). The lowest $\mathrm{Km}$ values of the enzyme with sodium alginate suggested that the enzyme had the higher affinity to sodium alginate than polyG.. 
Table 1. Specific activity and kinetic parameters of the recombinant enzyme aly-IV towards sodium alginate and polyG.

\begin{tabular}{cccc}
\hline Substrate & $\mathrm{Km}(\mathrm{g} / \mathrm{ml})$ & Vmax(OD235/h) & Relative Activty \\
\hline sodium alginate & 0.2223 & 3.6 & $100 \%$ \\
polyG & 0.3274 & 2.8321 & $68 \%$ \\
\hline
\end{tabular}

The datas were the means of three experimental repeats with the $\mathrm{SD}<0.05$. The initial reaction velocity was defined as the increasing absorbance at $235 \mathrm{~nm}$ of the products produced by recombinant enzyme aly-IV at the first five minites.

\subsection{Reaction products and modes of action}

To analyze the degradation products of the recombinant enzyme aly-IV, $5 \mu \mathrm{L}$ samples taken at different time were subjected to TLC assy. The distributions of the products from the substrates of sodium alginate and polyG were similar (Figure 8). The reaction products were further identified by negative ESI-TOF-MS. As reported in Figure 9, the degradation products of sodium alginate and polyG mainly consist of DP1, DP2, and DP3. The enzyme had no activity to polyM and polyGM(The dates not listed).
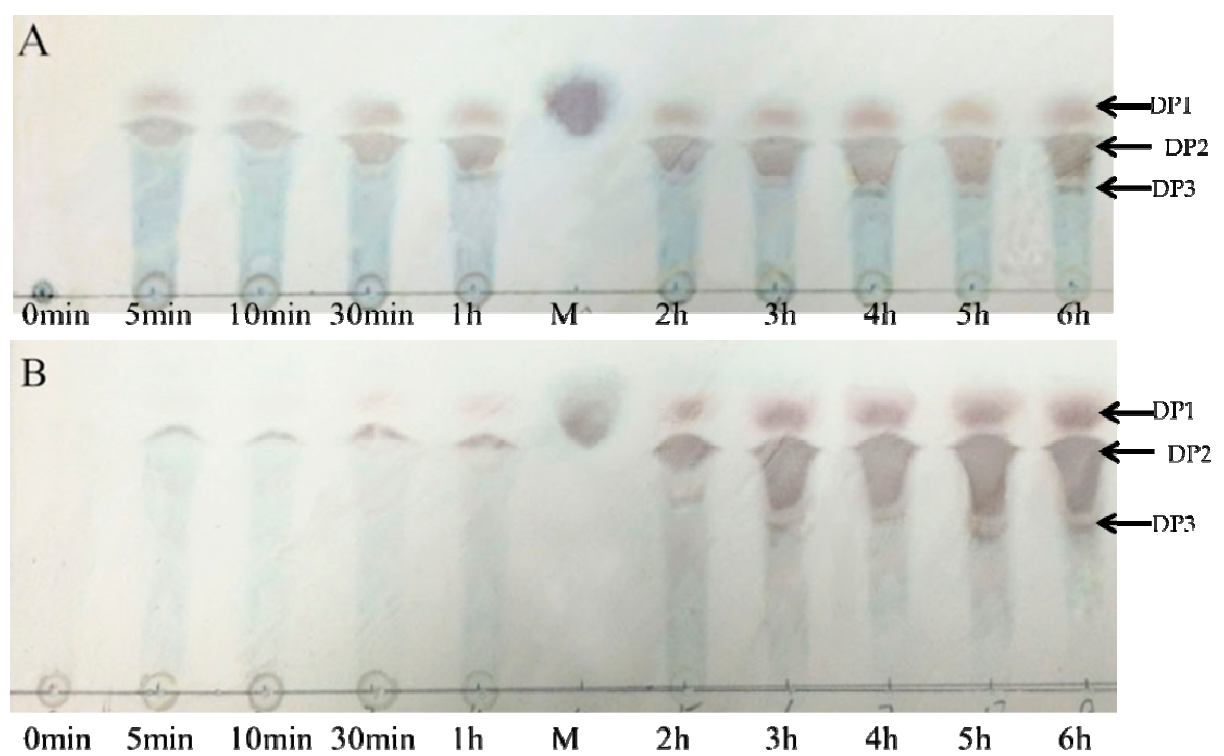

Figure 8. TLC analysis of the degradation products of the recombined enzyme towards sodium alginate and polyG. Samples were taken out at intervals. Line M: Galacturonic acid; (A) the TLC analyses for degradation products of sodium alginate. (B) the TLC plate analyses for degradation products of polyG. The solvent system was 1-butanol/ ethanol/ water 2:1:1 and products were visualized by heated the plate at $85{ }^{\circ} \mathrm{C}$ for $10 \mathrm{~min}$ after spray with a diphenylamine/ aniline/ phosphate reagent. 


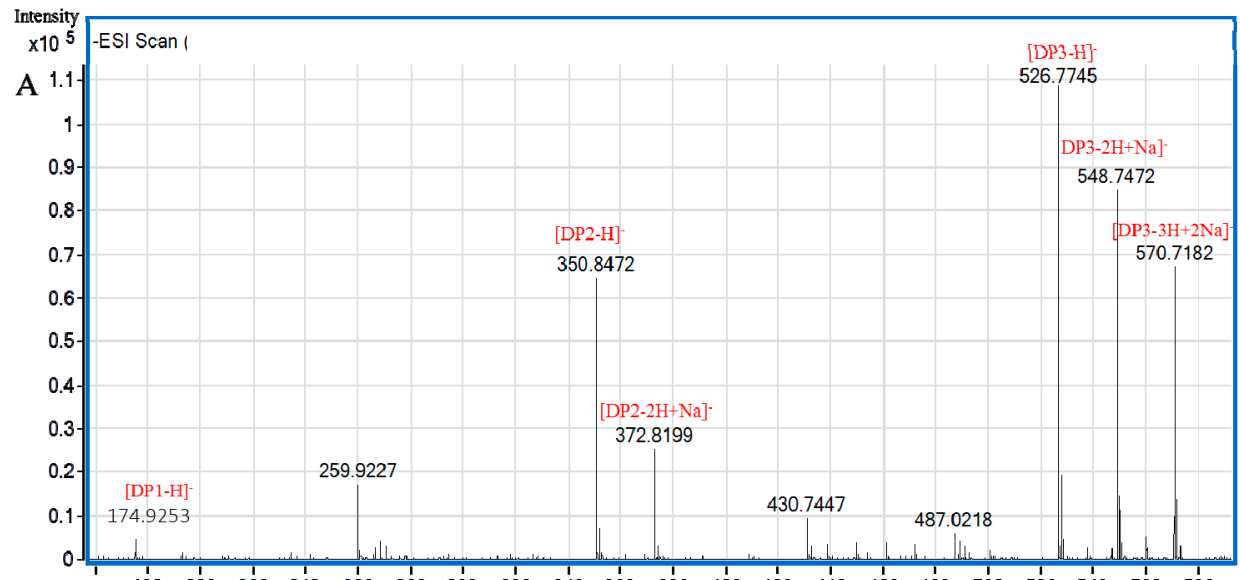

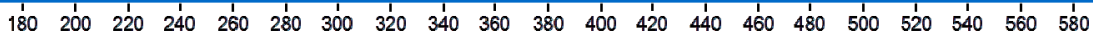

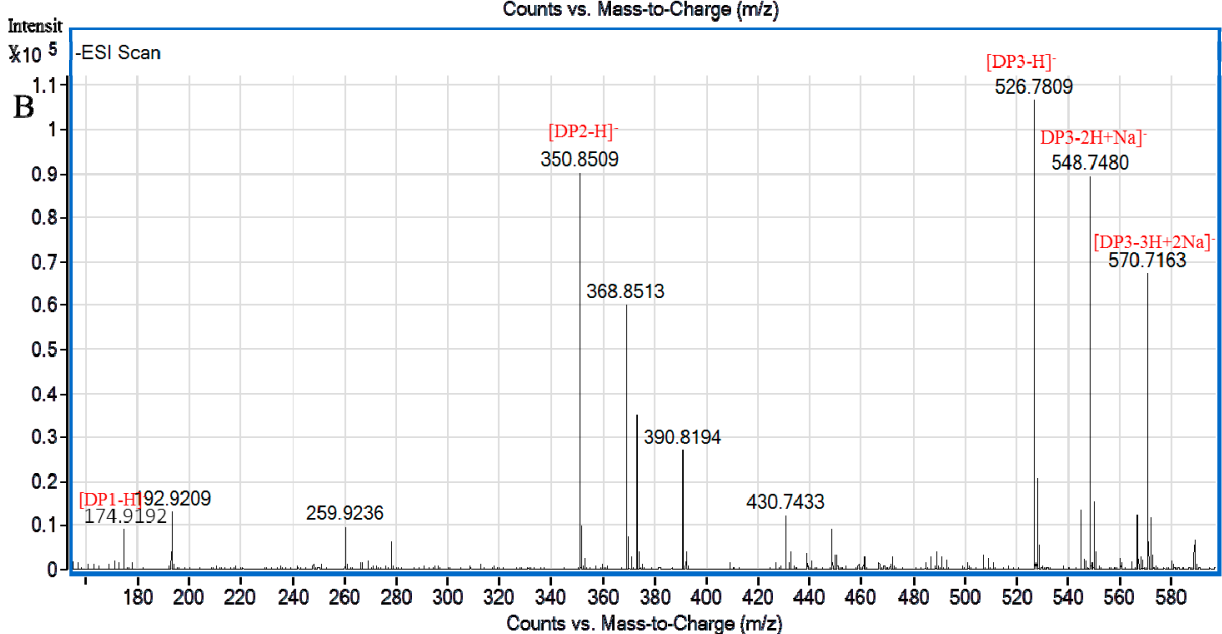

Figure 9. ESI-TOF-MS analyses of the end products of aly-IV. The samples applied to ESI-TOF-MS was reacted for $6 \mathrm{~h}$ (A) The degradation products of sodium alginate. (B) The degradation products of polyG.

The behavior of the recombined enzyme aly-IV was monitored in the viscometric assay. The viscosity of the alginate solution rapidly decreased in the first 5 minutes, whereas the values of $\mathrm{OD}_{520}$ $\mathrm{nm}$ increased very slowly (Figure 10). the distribution of the hydrolysate on the TLC plate suggested that the enzyme aly-IV acts in an endo-lytic mode. The endo-lytic mode actions of enzyme Alm from Agarivorans sp. JAM-A1m [22] and enzyme AlySY08 from Vibrio sp. SY08 [23] were confirmed in the same method. 


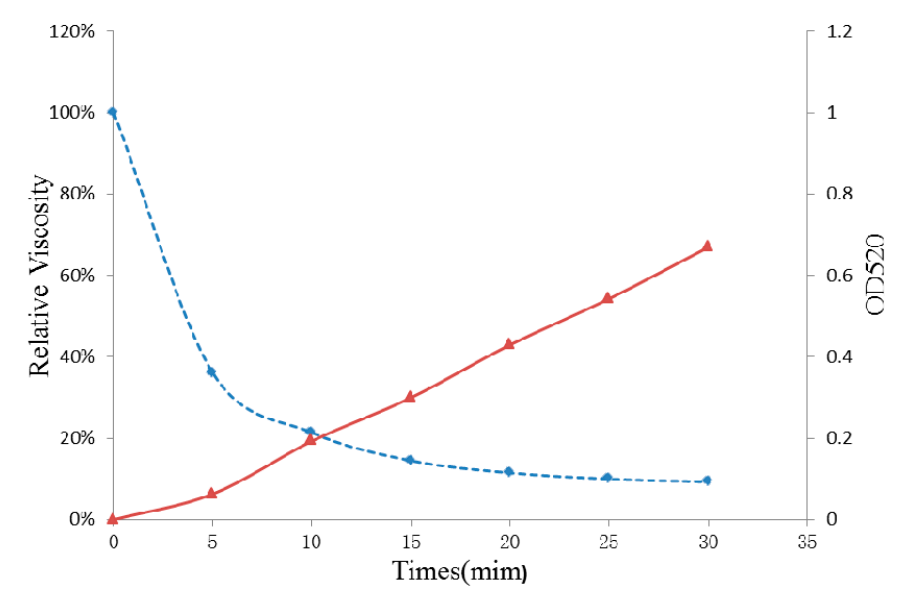

Figure 10. Viscosity reduction during enzymatic degradation of alginate. The initial viscosity of the reaction mixture was taken as $100 \%$. squares filled with dotted line rate of viscosity reduction; triangles filled with solid line absorbance at $520 \mathrm{~nm}$.

\section{Experimental Section}

\subsection{Isolation of alginate-degrading bacteria}

The rotten kelp samples collected from the seashore of Qingdao, China were suspended in sterile seawater and then spread on the alginate medium ( $\mathrm{pH} 7.2)$ plates containing $(\mathrm{w} / \mathrm{v}) 0.5 \%$ sodium alginate, $0.5 \%\left(\mathrm{NH}_{4}\right){ }_{2} \mathrm{SO}_{4}, 0.2 \% \mathrm{~K}_{2} \mathrm{HPO}_{4}, 0.1 \% \mathrm{MgSO}_{4}, 0.001 \% \mathrm{FeSO}_{4} \cdot 7 \mathrm{H}_{2} \mathrm{O}, 2 \%$ agar power. The plates were incubated at $28{ }^{\circ} \mathrm{C}$ for about $72 \mathrm{~h}$. Then the colonies showing hollow zone (Figure 1A) were picked up and purified on the same medium several times.

To determine the phylogenetic position of the strain QD-5, the $16 \mathrm{~S}$ rRNA gene sequence was amplified by polymerase chain reaction (PCR), and aligned with its closely related sequences retrieved from Genebank. The phylogenetic tree was constructed through neighbor-joining algorithm using MAGA 6.0.

\subsection{Genome sequencing and assembly}

Extracted from Vibrio sp. QD-5 using CTAB method, Genome DNA was sequenced using an Illumina Hiseq sequencing system accordingly. The acquired sequences were assembled using Velvet (2013) and submitted to Genebank (accession number of PRJNA382465). Contigs obtained from the HiSeq sequencing run were integrated with formerly sequenced reads and reassembled using paired-end.

\subsection{Construction, cloning and sequencing of the alginate lyase gene Aly-IV}

Vibrio sp. QD-5 was sequenced and the data of the genome were annotated (BerryGenomics, Beijing, China). A cluster of alginate lyase genes was found (Figure 2B), based on which Primers for cloning Aly-IV were designed. The forward primer was designed as $5^{\prime}$ TAGGTGGGATCCGATCATGAAGC-3' and the reverse primer was designed as 5'-AGAACTCGAGTTGGTACTTACC-3'. The DNA fragments with $1683 \mathrm{bp}$ (Figure 3) were amplified by PCR, and ligated into the vector pET-22b (+) in succession. The resultant plasmids were transformed into E.coil BL21 (DE3) cell. The positive clones were picked up, and the nucleotide sequences inserted into the plasmids were confirmed by DNA sequencing (GenScript, Nanjing, China).

\subsection{Sequence analyses of gene and proteins}

The ORFs (open reading frames) of the DNA sequence were translated into corresponding amino acid sequences using the translate tool on the ExPASy sever of SIB Bioinformatics Resource 
Portal (http://www.expasy.org/). Various physical and chemical parameters of the predicted protein were calculated using ProtParam (http://web.expasy.org/protparam/) tool in Swiss-Prot. The signal peptide in the alginate lyase was predicted using the SignalP 4.1 sever (http://www.cbs.dtu.dk/services/SignalP/). Functional information and the similarity sequences of the putative protein were performed on the National Center for Biotechnology Information server (NCBI) (https://www.ncbi.nlm.nih.gov/). Protein domains were identified using the NCBI and the Carbohydrate-Active Enzyme (CAZy) database (http://www.cazy.org). Phylogenetic tree of the predicted protein was constructed using MEGA 6.0.

\subsection{Production of recombinant aly-IV}

The recombined E. coli BL21 (DE3) cells with the constructed plasmid pET-22b (+)-Aly-IV were cultured in LB broth supplemented with $100 \mu \mathrm{g} / \mathrm{ml}$ ampicillin for about $3 \mathrm{~h}$ at $37^{\circ} \mathrm{C}$ and $200 \mathrm{rpm}$ in a shaking incubator. When cells grown up to an $\mathrm{OD}_{600}$ of $0.6 \sim 0.8$, the culture was supplemented with isopropyl- $\beta$-D-thiogalactopyranoside (IPTG) at a final concentration of $1 \mathrm{mM}$ to induce the expression of aly-IV. The cells were cultured for another $6 \mathrm{~h}$ at $37^{\circ} \mathrm{C}, 200 \mathrm{rpm}$ and harvested by centrifugation. For majorization expression, a series of parameters including IPTG concentration, postinduction temperature and time were varied.

\subsection{Preparation of inclusion body (IB) and purification of aly-IV}

The cells were harvested by centrifuging and disrupted by the high pressure cell cracker. After centrifuging at $10,000 \times \mathrm{g}$ for $10 \mathrm{~min}$, the reserved pellets were washed twice using the wash buffer (50 mM Tris- $\mathrm{HCl}, 2 \%$ TritonX-100) and then resuspended in the lysis buffer (50 mM Tris- $\mathrm{HCl}, 10 \%$ $(\mathrm{w} / \mathrm{v})$ sarkosyl, $10 \mathrm{mM} \beta$-mercaptoethanol) for overnight [24]. The solubilized IB was harvest by centrifuging at 10,000×g for $15 \mathrm{~min}$. Before affinity purification, the $10 \%(\mathrm{w} / \mathrm{v})$ sarkosyl-solublized IB solution was diluted with the lysis buffer to yield a $1 \%$ sarkosyl solution. For the efficiently purification, $2 \%$ TritonX-100 and 20 mM CHAPS in the $1 \%$ sarkosyl solution were necessary. The prepared solution was subjected to Ni-NTA Sepharose column (GE Healthcare, Uppsala, Sweden) pre-equilibrated with binding buffer $\left(20 \mathrm{mM} \mathrm{Na} 3 \mathrm{PO}_{4} \cdot 12 \mathrm{H}_{2} \mathrm{O}, 0.5 \mathrm{M} \mathrm{NaCl}, 10 \mathrm{mM}\right.$ imidazole). The fractions containing most of the target enzyme was eluted using elution buffer $(20 \mathrm{mM}$ $\mathrm{Na}_{3} \mathrm{PO}_{4} \cdot 12 \mathrm{H}_{2} \mathrm{O}, 0.5 \mathrm{M} \mathrm{NaCl}, 200 \mathrm{mM}$ imidazole) and pooled for the further purified using Superdex-200 Increase10/300 (GE Healthcare, Uppsala, Sweden). The enzyme was eluted with Tris- $\mathrm{HCl}$ buffer $(\mathrm{pH} 8.6)$ at a flow rate of $0.15 \mathrm{~mL} / \mathrm{min}$. Fractions with alginate lyase activity were gathered and stode at $-20{ }^{\circ} \mathrm{C}$. The purity of the fractions and the molecular weight of the enzyme were determined by SDS-PAGE (Figure 5). The concentration of the protein was measured by Coomassie Brilliant Blue G-250 with bovine serum albumin (BSA) as standard.

\subsection{Assay of the Recombined Alginate Lyase Activity}

The activity of the alginate lyase aly-IV was measured in a mixture solution containing $0.3 \%$ $(\mathrm{w} / \mathrm{v})$ sodium alginate solubilized in $50 \mathrm{mM}$ Tris- $\mathrm{HCl} \mathrm{pH} 8.9(0.9 \mathrm{~mL})$ and a suitably enzyme solution $(0.1 \mathrm{~mL})$ at $35^{\circ} \mathrm{C}$ for $10 \mathrm{~min}$. The reaction was terminated in boiling water for $10 \mathrm{~min}$. The enzyme activity was determined as the increase in the absorbance $235 \mathrm{~nm}$. One unit $(\mathrm{U})$ was defined as the amount of enzyme required to increase by 0.1 the absorbance at $235 \mathrm{~nm}$ per minute.

\subsection{Enzymatic degradation of sodium alginate}

$0.1 \mathrm{~mL} 0.5 \%$ sodium alginate, $0.05 \mathrm{~mL}$ of enzyme and $0.15 \mathrm{~mL} 50 \mathrm{mM}$ Tris- $\mathrm{HCl}$ were mixed in $1.5 \mathrm{~mL}$ EP tube, and then the mixture was incubated at $35^{\circ} \mathrm{C}$. After incubated for $0.5 \mathrm{~h}, 1 \mathrm{~h}, 2 \mathrm{~h}, 3 \mathrm{~h}$, $4 \mathrm{~h}, 5 \mathrm{~h}, 6 \mathrm{~h}, 12 \mathrm{~h} 24 \mathrm{~h}$, and $36 \mathrm{~h}$, the samples were taken to determine the absorbance at $520 \mathrm{~nm}$. 


\subsection{Substrate Specificity and Kinetic parameters of the Recombined Enzyme}

$50 \mu \mathrm{L}$ purified enzyme was added to the reaction mixture containing $0.5 \%$ of sodium alginate and polyG, respectively, for the substrate specificity. Enzyme activity was measured as described previously.

Kinetic parameters of the enzyme towards sodium alginate and polyG were obtained by measuring the enzyme activity with substrate of different concentrations $(0.1-1 \mathrm{~g} / \mathrm{mL})$ (Table 1$)$. The initial velocities were measured in the first five minute in the standard assay mixture. The $\mathrm{Km}$ and $V$ max values were analyzed using the Eadie-Hofstee method.

\subsection{Characterization of the Recombined Alginate Lyase}

The temperature effects on the enzyme towards sodium alginate were performed at $\mathrm{pH} 8.9$ in different temperature of $0-55^{\circ} \mathrm{C}$ (Figure 6A). The thermal stability of the enzyme towards sodium alginate was determined by measuring the enzyme activity after incubated at 0-55 ${ }^{\circ} \mathrm{C}$ for $30 \mathrm{~min}$ (Figure 6B). The $\mathrm{pH}$ effects on the enzyme towards sodium alginate were performed at $35{ }^{\circ} \mathrm{C}$ in different $\mathrm{pH}$ of 5-10.5 (Figure 6C). The $\mathrm{pH}$ stability of the enzyme towards sodium alginate was determined by measuring the residual enzyme activity after incubated at different $\mathrm{pH}$ for $3 \mathrm{~h}$ in ice-bath(Figure 6D).

The influences of $\mathrm{NaCl}$ on the enzyme were performed by adding different concentration of $\mathrm{NaCl}(1-45 \mathrm{mM})$ to the reaction system as mentioned before. The enzyme activity without $\mathrm{NaCl}$ served as control (Figure 7A). The effects of metal ions on the enzyme were carried out by measuring the enzyme activity in the present of metal ions. The reaction mixture without any metal ion was taken as control (Figure 7B).

\subsection{Analysis of reaction mode and products}

The degraded products of the recombined enzyme aly-IV were analyzed using thin-layered chromatography (TLC) (TLC silica gel 60 F254, Merck KGaA, Darmstadt, Germany). The digested samples were periodically withdrawn for TLC analysis. The products on the TLC plates were developed using a solvent system of 1-butanol/ ethanol/ water 2:1:1 and then visualized by heating the plates at $85{ }^{\circ} \mathrm{C}$ for $10 \mathrm{~min}$ after spraying with a diphenylamine/ aniline/ phosphate reagent (Figure 8). To further determine the products of the enzymatic action, the ESI-TOF-MS was conducted. $5 \mu \mathrm{L}$ samples with $6 \mathrm{~h}$ reaction time were loop-injected to a G1969A time of flight mass spectrometer (TOF-MS) (Agilent Technologies Inc., California, USA) after filtration with $0.22 \mu \mathrm{m}$ filter membrane (Figure 9). The products were detected in a negative-ion mode using the following settings: pressure of the atomizer $\left(\mathrm{N}_{2}\right), 40 \mathrm{psi}$; flow rate of the dryer $\left(\mathrm{N}_{2}\right), 11 \mathrm{~L} / \mathrm{min}$; temperature of the dryer $\left(\mathrm{N}_{2}\right), 350{ }^{\circ} \mathrm{C}$; capillary voltage, $4000 \mathrm{~V}$; scanning the mass range, $100-1000 \mathrm{~m} / \mathrm{z}$.

To determine the reaction mode of the recombined enzyme aly-IV, the viscometric parameters were measured with a rotary viscosimeter (SNB-1; Sunny Hengping Scientific instrument co., LTD, shanghai, China). The reaction mixtures contained $3 \mathrm{~mL}$ enzyme aly-IV and $27 \mathrm{~mL} 1.5 \%$ sodium alginate dissolved in $50 \mathrm{mM}$ Tris- $\mathrm{HCl}, \mathrm{pH}$ 8.9. The viscosity was measured at $35^{\circ} \mathrm{C}$ at timed interval and the timed samples $(0.3 \mathrm{~mL})$ were taken out for the measurement of the absorbance at $520 \mathrm{~nm}$ (Figure 10).

\section{Conclusions}

In this study, an alginate lyase gene, Aly-IV, was cloned and expressed in E.coil BL21. The purification and characterization of this enzyme was reported for the first time. Its optimal temperature and $\mathrm{pH}$ was $35^{\circ} \mathrm{C}$ and 8.9, respectively. Like other alginate lyases, such as AL-128 from Vibrio harveyi [25], rA9mT from Vibrio sp. JAM-A9m [26], AIYSY08 from Vibrio sp. SY08 [23], aly-IV was also a salt-activated enzyme, which its activity was increased 3 times at $15 \mathrm{mM} \mathrm{NaCl}$. Aly-IV may be activated by $\mathrm{K}^{+}, \mathrm{Mg}^{2+}$ and $\mathrm{Ca}^{2+}$, that was similar to other polyG-specific alginate lyase.

As shown in Figure 4, PL7 alginate lyases contain three highly conserved amino acid sequences, $(\mathrm{S} / \mathrm{T} / \mathrm{N}) \mathrm{EL}, \mathrm{Q}(\mathrm{I} / \mathrm{V}) \mathrm{H}$, and $\mathrm{YFKAG}(\mathrm{V} / \mathrm{I}) \mathrm{YNQ}$, which were thought to play an important role in 
catalytic activity or the folding of the structure [27]. Researches revealed that enzymes containing QIH or QVH in the conserved region had substrate specificity of G-block and M-block, respectively [28]. However, aly-IV seems to perfer poly-G, like ALY-1 from Corynebacterium sp. ALY-1 [29], A1-I from Sphingomonas sp.A1 [30] and A1m from Agarivorans sp. JAM-A1m [31], whose of them preferred polyG as the substrate.

Alginate extracted from seaweed has had a wide range of applications A lot of organisms are also able to exploit $\mathrm{M}$ and $\mathrm{G}$ units from depolymerized alginates as carbon and energy sources. Most of them can secrete the alginate lyase to degrade alginate. So far, hundreds of alginate lyases were found from a variety of organisms, such as marine algae, marine mollusks (Littorina spp., Haliotis spp., Turbo cornutus.), and a wide range of marine and terrestrial bacteria. Alginate lyases belong to a member of the polysaccharise lyases. But the question concerned is why so many organism produce alginate lyase, including even the bacteria from deep-sea [32]? Isn't the alginate everywhere? Why are the gene sequences of alginate lyases from the different sources so diverse [33]? But so far, these questions remained unanswered. We speculate that alginate lyase can not only degrade alginate, may also degrade other polysaccharides, for example, alginate lyase in organisms has the multiple substrate specificities. Although no report has been seen yet, we will attempt to confirm this speculation in future.

Acknowledgments: This research was supported by the National Basic Research Program of China (973 Program) (No. 2015CB755906), the Public Welfare Project of SOA (No. 201505032).

Author Contributions: Yaxi Chao performed the construction of the heterologous expression system, purification of the enzyme, characterization of the enzymatic properties and wrote the manuscript. Shuyan Wang carried out the isolation of the marine bacteria. Suqi Wu performed the work of bioinformatics analysis.Hao Chen designed the study and revised the manuscript.

Conflicts of Interest: The authors declare no conflict of interest.

\section{References}

1. Gacesa, P. Alginates. Carbohydrate Polymers. 1988, 8, 161-182, doi: 10.1016/0144-8617 (88) 90001-X.

2. Goh C. H.; Heng P. W. S.; Lai W. C. Alginates as a useful natural polymer for microencapsulation and therapeutic applications. Carbohydrate Polymers. 2012, 88, 1-12, doi: 10.1016/j.carbpol. 2011.11.012.

3. Chapman V. J.; Chapman D. J. Seaweeds and their Uses. 1st ed.; Springer: Springer Netherlands, Netherlands, 1980; pp. 194-225.

4. Tramper, J.; De Man, A. W. A. Characterization of Nitrobacter agilis immobilized in calcium alginate. Enzyme and Microbial Technology. 1986, 88, 472-476, doi: 10.1016/0141-0229 (86) 90050-5.

5. Choi, H. G.; Kim, C. K. Development of omeprazole buccal adhesive tablets with stability enhancement in human saliva. Journal of Controlled Release. 2000, 68(3), 397-404, doi: 10.1016/ S0168-3659 (00) 00276-5.

6. Kimura, Y.; Watanabe, K.; Okuda, H. Effects of soluble sodium alginate on cholesterol excretion and glucose tolerance in rats. Journal of Ethnopharmacology. 1996, 54(1), 47-54, doi: 10.1016/0378- 8741 (96) 01449-3.

7. Day D. F. Biopolymers from Renewable Resources. 1st ed.; Springer: Berlin Heidelberg, Germany, 1998, pp. 119-143.

8. An Q. D.; Zhang G. L.; Wu H. T.; Zhang Z. C.; Zheng G. S.; Luan L.; Murata Y.; Li X. Alginate-deriving oligosaccharide production by alginase from newly isolated Flavobacterium sp. LXA and its potential application in protection against pathogens. J Appl Microbiol. 2009, 106, 161-170, doi:10. 1111/j.1365-2672. 2008. 03988.x.

9. Iwasaki K. I.; Matsubara Y. Purification of alginate oligosaccharides with root growth-promoting activity toward lettuce. Biosci Biotechnol Biochem. 2000, 64, 1067-1070, doi: 10.1271/bbb. 64. 1067.

10. Wong T. Y.; Preston L. A.; Schiller N. L. Alginate lyase: review of major sources and enzyme characteristics, 
structure-function analysis, biological roles, and applications. Annual Reviews in Microbiology. 2000, 54(1), 289-340, doi: 10. 1146/annurev.micro. 54. 1. 289.

11. Park H. H.; Kam N.; Lee E. Y.; Kim H. S. Cloning and Characterization of a Novel Oligoalginate Lyase from a Newly Isolated Bacterium Sphingomonas sp. MJ-3. Mar Biotechnol. 2012, 14(2), 189-202, doi: 10.1007/s10126-011-9402-7.

12. Huang L.; Zhou J.; Li X.; Peng Q.; Lu H.; Du Y. Characterization of a new alginate lyase from newly isolated Flavobacterium sp. S20. Ind Microbiol Biotechnol. 2013, 40, 113-122, doi: 10.1007/ s10295-012-1210-1.

13. Østgaard K. Determination of alginate composition by a simple enzymatic assay. Hydrobiologia. 1993, 260-261(1), 513-520, doi: 10.1007/BF00049064.

14. Boyen C.; Bertheau Y.; Barbeyron T.; Kloareg B. Preparation of guluronate lyase from Pseudomonas alginovora for protoplast isolation in Laminaria. Enzyme Microb Technol. 1990, 12, 885-890, doi: 10.1016/0141-0229 (90) 90027-N.

15. Alkawash M. A.; Soothill J. S.; Schiller N. L. Alginate lyase enhances antibiotic killing of mucoid Pseudomonas aeruginosa in biofilms. APMIS. 2006, 114, 131-138, doi: 10.1111/j.1600-0463. 2006. apm_356.x.

16. Tamura K.; Peterson D.; Peterson N.; Stecher G.; Nei M.; Kumar S. MEGA5: molecular evolutionary genetics analysis using maximum likelihood, evolutionary distance, and maximum parsimony methods. Mol Biol Evol. 2011, 28, 2731-2739, doi: 10.1093/molbev/msr121.

17. Swift S. M.; Hudgens J. W.; Heselpoth R. D.; Bales P. M.; Nelson D. C. Characterization of AlgMsp, an Alginate Lyase from Microbulbifer sp. 6532A. PLoS ONE. 2014, 9(11), 1-11, doi: 10.1371/journal. pone.0112939.

18. Kawamoto, H.; Horibe, A.; Miki, Y.; Kimura, T.; Tanaka, K.; Nakagawa, T. Cloning and sequencing analysis of alginate lyase genes from the marine bacterium Vibrio sp. O2. Mar.Biotechnol. 2006, 8, 481-490, doi: 10.1007/s10126-005-6157-z.

19. Yamasaki, M.; Moriwaki, S.; Miyake, O.; Hashimoto, W.; Murata, K.; Mikami, B. Structure and function of a hypothetical Pseudomonas aeruginosa protein PA1167 classified into family PL-7: a novel alginate lyase with a beta-sandwich fold. J. Biol.Chem. 2004, 279, 31863-31872, doi: 10.1074/jbc. M402466200.

20. Sim, S. J.; Baik, K. S.; Park, S. C.; Han, N. C.; Chi, N. S.; Shin, T. S.; Woo H. Ch.; Cho J. Y.; Kim D. Characterization of alginate lyase gene using a metagenomic library constructed from the gut microflora of abalone. Ind Microbiol Biotechnol. 2012, 39, 585-593, doi: 10.1007/s10295-011-1054-0.

21. Li S.; Yang X.; Zhang L.; Yu W.; Han F. Cloning, Expression, and Characterization of a Cold-Adapted and Surfactant-Stable Alginate Lyase from Marine Bacterium Agarivorans sp. L11. Microbiol. Biotechnol. 2015, 25(5), 681-686, doi: 10.4014/jmb.1409. 09031.

22. Kobayashi T.; Uchimura K.; Miyazaki M.; Nogi Y.; Horikoshi K. A new high-alkaline alginate lyase from a deep-sea bacterium Agarivorans sp. Extremophiles. 2009, 13, 121-129, doi: 10.1007/ s00792-008-0201-7.

23. Li S. Y.; Wang L. N.; Hao J. H.; Xing M. X, Sun J. J.; Sun M. Purification and Characterization of a New Alginate Lyase from Marine Bacterium Vibrio sp. SY08. Mar. Drugs. 2017, 15(1), 1, doi: 10.3390/md15010001. http://www.mdpi.com/1660-3397/15/1/1.

24. Tao H.; Liu W.; Simmons B. N.; Harris H. K.; Cox T. C.; Massiah M. A. Purifying natively folded proteins from inclusion bodies using sarkosyl, Triton X-100, and CHAPS. Biotechniques, 2010, 48(1), 61-64, doi: $10.2144 / 000113304$.

25. Kitamikado M, Tseng $\mathrm{C} \mathrm{H}$, Yamaguchi $\mathrm{K}$, et al. Two types of bacterial alginate lyases. Applied $\mathcal{E}$ Environmental Microbiology, 1992, 58(8), 2474-8, PMCID: 195806

26. Uchimura K, Miyazaki M, Nogi Y, et al. Cloning and sequencing of alginate lyase genes from deep-sea 
strains of Vibrio and Agarivorans and characterization of a new Vibrio enzyme. Marine Biotechnology, 2010, 12(5), 526-533, doi: 10.1007/s10126-009-9237-7

27. Zhu B, Yin H. Alginate lyase: Review of major sources and classification, properties, structure-function analysis and applications. Bioengineered, 2015, 6(3), 125, doi: 10.1080/21655979.2015.1030543

28. Yamasaki M, Ogura $\mathrm{K}$, Hashimoto $\mathrm{W}$, et al. A structural basis for depolymerization of alginate by polysaccharide lyase family-7. Journal of Molecular Biology, 2005, 352(1), 11-21, doi: 10.1016/j.jmb.2005.06.075

29. Matsubara Y, Iwasaki K, Muramatsu T. Purification and characterization of extracellular alginate lyase from Corynebacterium sp. ALY-1 strain. The Society for Biotechnology, Japan, 1995, PMID: 16232727

30. Miyake O, Hashimoto W, Murata K. An exotype alginate lyase in Sphingomonas sp. A1: overexpression in Escherichia coli, purification, and characterization of alginate lyase IV (A1-IV). Protein Expression $\mathcal{E}$ Purification, 2003, 29(1), 33, doi: 10.1016/S1046-5928(03)00018-4

31. Kobayashi T, Uchimura K, Miyazaki M, et al. A new high-alkaline alginate lyase from a deep-sea bacterium Agarivorans sp. Extremophiles Life Under Extreme Conditions, 2009, 13(1), 121, doi: 10.1007/s00792-008-0201-7

32. WongT. Y.; Preston L. A.; Schiller N. L. Alginate lyase: review of major sources and enzyme characteristics, structure-function analysis, biological roles, and applications. Annu. Rev. Microbiol. 2000, 54, 289-340, doi: 10.1146/annurev. micro.54. 1. 289.

33. Uchimura K.; Miyazaki M.; Nogi Y.; Kobayashi T.; Horikoshi K. Cloning and Sequencing of Alginate Lyase Genes from Deep-Sea Strains of Vibrio and Agarivorans and Characterization of a New Vibrio Enzyme. Mar Biotechnol. 2010, 12, 526-533, doi:10.1007/s10126-009-9237-7. 